\title{
KEMAMPUAN BERPIKIR KRITIS DAN HASIL BELAJAR KOGNITIF SISWA MENGGUNAKAN MODEL PEMBELAJARAAN KOOPERATIF TIPE THINK PAIR SHARE (TPS) DI MAN 2 KOTA BENGKULU
}

\author{
Neni Murniati ${ }^{1 *}$, Rahmatika Febyasha ${ }^{2}$, Irwandi ${ }^{2}$ \\ ${ }^{1}$ Program Studi Pendidikan Biologi, Fakultas Keguruan dan Ilmu Pendidikan Universitas Bengkulu \\ ${ }^{2}$ Program Studi Pendidikan Biologi, Fakultas Keguruan dan IImu Pendidikan Universitas Muhammadiyah \\ Bengkulu \\ Email: nenimurniati@unib.ac.id
}

\begin{abstract}
Abstrak
Penelitian ini bertujuan untuk mengetahui kemampuan berpikir kritis dan hasil belajar kognitif siswa pada pembelajaran biologi menggunakan model pembelajaraan kooperatif tipe Think Pair Share (TPS) di MAN 2 Kota Bengkulu. Penelitian ini dilakukan dengan metode kuasi eksperimen. Desain penelitian yang digunakan adalah randomized control-group pretest posttest design. Sampel penelitian ini adalah siswa kelas X MIA yang diambil 2 kelas secara acak (random sampling). Kelas pertama dengan pembelajaran model Think Pair Share (TPS), kelas kedua dengan pembelajaran model konvensional. Pengumpulan data penelitian menggunakan instrumen berupa tes esai untuk berpikir kritis dan tes objektif dengan lima option untuk hasil belajar kognitif. Analisis data menggunakan adalah uji-t independent samples test. Hasil penelitian menunjukkan bahwa terdapat perbedaan hasil berpikir kritis dan hasil belajar kognitif siswa biologi model pembelajaran kooperatif type Think Pair Share (TPS) terhadap di MAN 2 Kota Bengkulu. Berdasarkan hasil penelitian diperoleh nilai ratarata kelas eksperimen kemampuan berpikir kritis yakni 88,9 dan hasil belajar kognitif siswa yakni 85,9
\end{abstract}

Kata Kunci : Think Pair Share (TPS), Hasil Belajar Kognitif, Berpikir Kritis.

\begin{abstract}
This study aims to determine the ability of critical thinking and cognitive learning outcomes of students in learning biology using the cooperative learning model Think Pair Share (TPS) type in Islamic Senior High School number 2 Bengkulu City. This research was conducted by the quasi experimental method. The research design used was randomized control-group pretest posttest design. The sample of this study was students of class X MIA (Mathematics and natural science) who were taken 2 classes randomly assigned. The first class with Think Pair Share (TPS) learning model, the second class with conventional learning model. Research data collection uses instruments in the form of essay tests for critical thinking and objective tests with five options for cognitive learning outcomes. Data analysis using is the independent samples t-test. The results showed that there were differences in critical thinking and cognitive learning outcomes of biology students in the cooperative learning model Think Pair Share (TPS) type in Islamic Senior High School number 2 Bengkulu City. Based on the results of the study obtained an average value of critical thinking experimental class that is 88.9 and cognitive learning outcomes of students is 85.9.
\end{abstract}

Keywords: Think Pair Share (TPS), Cognitive Learning Outcome, Crtitical Thinking 


\section{PENDAHULUAN}

Pendidikan diartikan sebagai suatu kegiatan yang sistematis dan sistemik terarah kepada terbentuknya kepribadian peserta didik. Sistematis artinya proses pendidikan berlangsung melalui tahaptahap berkesinambungan, sedangkan sistemik berarti proses pendidikan berlangsung dalam semua kondisi, lingkungan, sekolah, dan masyarakat (Tirtarahardja dan Sulo, 2010). Untuk menghasilkan suatu perubahan kepribadian, peserta didik harus mampu melaksanakan proses pembelajaran di sekolah. Hal ini sangat penting dalam mempengaruhi karakter peserta didik dan memberikan mereka pengalaman belajar dan berbagai kegiatan yang akan dilakukan.

Belajar merupakan kegiatan yang dilakukan seseorang sehari-hari. Kegiatan tersebut dapat dihayati (dialami) oleh orang yang sedang belajar. Disamping itu, kegiatan belajar juga dapat diamati oleh orang lain. Belajar yang terjadi pada individu merupakan perilaku kompleks, tindak interaksi antara siswa dengan guru (Dimyati \& Mudjiono,2013). Pembelajaran merupakan aktivitas pertama dalam proses pendidikan di sekolah. Proses pembelajaran merupakan interaksi antara guru dengan siswa. Proses tersebut bukan hanya melalui pemberian informasi dari guru kepada siswa tanpa mengembangkan gagasan kreatif siswa, melainkan melalui komunikasi timbal balik antara guru dengan siswa. Dalam komunikasi timbal balik ini siswa diberi kesempatan untuk terlibat aktif dalam belajar baik mental, intelektual, emosional, maupun fisik agar mampu mencari dan menemukan pengetahuan, sikap, dan keterampilan (Ruswandi, 2013).

Dalam proses pembelajaran yang aktif, interaksi antara guru dengan siswa akan memacu siswa untuk mengeluarkan pendapat atau berpikir secara kritis dan logis, sehinggga dapat berpengaruh terhadap cara belajar mereka. Untuk itu pemahaman guru terhadap pengertian pembelajaran akan mempengaruhi cara guru itu mengajar agar keberhasilan pencapaian tujuan pendidikan bisa tercapai dengan efektif (Slameto. 2010)

$$
\text { Tujuan pembelajaran menjadi }
$$

salah satu aspek yang perlu dipertimbangkan dalam merencanakan pembelajaran. Sebab segala kegiatan pembelajaran bermuara pada tercapainya tujuan tersebut. Penuangan tujuan pembelajaran bukan saja memperjelas arah yang ingin dicapai dalam suatu kegiatan belajar, tetapi dari segi efisiensi diperoleh hasil yang maksimal. Keuntungan yang dapat diperoleh melalui penuangan tujuan pembelajaran tersebut adalah : (1) waktu mengajar dapat dialokasikan dan dimanfaatkan secara tepat. (2) guru dapat menetapkan berapa banyak materi pelajaran yang dapat disajikan dalam setiap jam pelajaran. (3) guru dapat dengan mudah menetapkan dan mempersiapkan strategi belajar mengajar yang cocok dan menarik. (4) guru mudah mempersiapkan berbagai keperluan peralatan maupun bahan dalam keperluan belajar. (5) guru dapat mengukur keberhasilan siswa dalam belajar (Hamzah dan Uno, 2008).

Kemampuan berpikir kritis merupakan keterampilan mengeluarkan argument dengan suatu penalaran yang logis. Penalaran yang logis didasarkan pada pemikiran tingkat tinggi dan wawasan dalam memahami tiap-tiap makna permasalahan. (Kuswana, 2011) Keterampilan berpikir merupakan aspek yang penting dan sangat dibutuhkan oleh setiap individu dalam mengatasi berbagai permasalahan dalam kehidupan. Keterampilan berpikir kritis adalah bagian keterampilan berpikir yang perlu dioptimalkan melalui proses pembelajaran di sekolah. Dalam proses pembelajaran 
aspek keterampilan berpikir kritis turut menentukan keberhasilan belajar siswa (Mamu, 2014). Keterampilan berpikir kritis meliputi kemampuan : (a) mengenal masalah, (b) menemukan cara-cara yang dapat dipakai untuk mengenai masalahmasalah itu, (c) mengumpulkan dan menyesuaikan informasi yang diperlukan, (d) mengenal asumsi-asumsi dan nilainilai yang tidak dinyatakan, (e) memahami dan menggunakan bahasa yang tepat, jelas, dan khas, (f) menganalisis data, (g) menilai fakta dan mengevaluasi pernyataan-pernyataan, (h) mengenal adanya hubungan yang logis antara masalah-masalah, (i) menarik kesimpulankesimpulan dan kesamaan-kesamaan yang diperlukan, (j) menguji kesamaankesamaan dan kesimpulan-kesimpulan yang seseorang ambil, (k) menyusun kembali pola-pola keyakinan seseorang berdasarkan pengalaman yang lebih luas, dan (I) membuat penilaian yang tepat tentang hal-hal dan kualitas-kualitas tertentu dalam kehidupan sehari-hari. (Fisher,2008; Feldman, 2010)

Hasil belajar peserta didik terdiri dari ranah kognitif, afektif, dan psikomotor. Hasil belajar pada ranah kognitif peserta didik dituntut mampu menghasilkan pengetahuan-pengetahuan yang dimiliki secara maksimal. Berdasarkan jenjang kognitif taksonomi Bloom domain kognitif revisi Anderson \& Krathwohl (2001) yaitu: (1) mengingat, (2) memahami, (3) menerapkan, (4) menganalisis, (5) evaluasi, dan (6) mencipta (Krathwohl, 2002).

Model pembelajaran yang menekankan pentingnya kerja kelompok agar semua siswa secara bersama-sama dapat mencapai tingkat penguasaan belajar sesuai dengan yang diharapkan adalah model pembelajaran kooperatif. Model ini sangat bermanfaat untuk pengorganisasian siswa dan interaksi belajar sehingga siswa dapat bekerja sama secara kooperatif dalam meningkatkan hasil belajarnya (Irwandi, 2010).

Berdasarkan hasil observasi dan wawancara terhadap guru biologi kelas $X$ MIA MAN 2 Kota Bengkulu diketahui bahwa proses pembelajaran sudah menggunakan kurikulum 2013 (K13). Namun, proses belajar mengajar di kelas $X$ MIA belum menerapkan model pembelajaran yang tepat. Diketahui bahwa keterampilan berpikir kritis dan hasil belajar kognitif siswa pada mata pelajaran biologi khususnya kelas X MIA masih rendah yakni dengan rata-rata 67,80 sebanyak $65 \%$. Sedangkan standar nilai Kriteria Ketuntasan Minimal (KKM) telah dianggap berhasil apabila peserta didik telah mencapai nilai ratarata 75 sebanyak $85 \%$. Hal itu disebabkan saat proses pembelajaran $d$ ikelas masih terlihat sebagian siswa yang masih pasif dalam melakukan tanya jawab serta belum efektif mengembangkan kemampuan berpikir kritis. Kemampuan berpikir kritis sangat penting untuk dikembangkan dalam proses pembelajaran, karena siswa dituntut untuk mengeluarkan pikirannnya dalam membantu memecahkan masalah dan berpikir secara mendalam.

Solusi yang dapat dilakukan oleh guru untuk meningkatkan kualitas proses pembelajaran adalah dengan cara menggunakan model pembelajaran yang tepat. Model yang dapat meningkatkan cara berpikir kritis serta hasil belajar kognitif siswa salah satunya adalah dengan menggunakan model pembelajaran type Think Pair Share (TPS). Model pembelajaran kooperatif tipe Think Pair Share merupakan model pembelajaran kooperatif yang efektif untuk membuat variasi suasana pola diskusi. Prosedur yang digunakan dalam model Think Pair Share dapat memberi siswa lebih banyak waktu berpikir, merespon dan saling membantu 
(Kurniasih dan Sani, 2015). Mengacu pada permasalahan di atas, maka tujuan penelitian ini mengetahui kemampuan berpikir hasil Belajar Kognitif Siswa Man 2 Kota Bengkulu Menggunakan Model Pembelajaraan Kooperatif Tipe Think Pair Share (TPS).

\section{METODE PENELITIAN}

Penelitian ini merupakan jenis penelitian dengan metode kuasi eksperimen. Desain penelitian ini menggunakan rancangan randomized control-group pretest- posttest design. Penelitian ini dilaksanakan di kelas X MAN 2 Kota Sampel diambil secara Random Sampling (pengambilan sampel dilakukan secara acak) pada pokok bahasa pencemaran lingkungan. Sampel yang digunakan dua kelompok sampel penelitian yaitu kelompok eksperimen dan kelompok kontrol. Instrumen penelitian yang digunakan untuk mengumpulkan data dalam penelitian ini adalah tes objektif dengan lima option (untuk hasil belajar kognitif) dan tes essay (untuk berpikir kritis) yang diberikan kepada kelas sampel yang terdiri dari: 1). Merumuskan masalah, 2) memberikan argumen, 3) melakukan deduksi, 4) melakukan induksi, 5) melakukan evaluasi, 6) mengambil keputusan dan tindakan (Ennis, 2005). Teknik pengumpulan data dengan tes yang dilakukan sesuai dengan materi pelajaran yang diberikan selama perlakuan berlangsung dan dilakukan tes. Tes diberikan sebelum (pretest) dan sesudah (posttest) proses pembelajaran. Analisis data yang digunakan yaitu dengan $u j i ~ t$, proses pengolahan datanya dengan menggunakan program komputer Static Package For Social Science (SPSS) for window versi 20. Sebelum melakukan uji terlebih dahulu akan dilakukan uji prasyarat yaitu, uji normalitas, dan uji homogenitas varian.

\section{HASIL DAN PEMBAHASAN}

Berdasarkan Penelitian yang telah dilakukan diperoleh data Hasil penelitian dari berpikir kritis dan hasil belajar kognitif siswa. Data kemudian dianalisis dengan dua tahap yaitu analisis data tahap awal (pre-test) dan analisis data tahap akhir (post-test). Bentuk soal tes essay yang diberikan untuk berpikir kritis dan soal tes objektif dengan lima option untuk hasil belajar kognitif.

\section{Pretest Hasil belajar Siswa}

Data yang diperoleh dan dianalisis dalam penelitian ini adalah skor dari hasil tes kemampuan berpikir kritis dan hasil belajar kognitif siswa pada mata pelajaran biologi dikelas X MIA di MAN 2 Kota Bengkulu. Skor hasil pretest kemampuan berpiikir kritis dapat dilihat pada Tabel 1.

Tabel 1. Perhitungan Skor Kemampuan Berpikir Kritis Berdasarkan Tes Awal (Pretest)

\begin{tabular}{ccc}
\hline & \multicolumn{2}{c}{ Kelas } \\
\hline Perhitungan & $\begin{array}{c}\text { Eksperimen } \\
\text { (Model Think Pair } \\
\text { Share) }\end{array}$ & $\begin{array}{c}\text { Kontrol } \\
\text { (Model } \\
\text { Konvensional) }\end{array}$ \\
\hline Jumlah Skor & 1446 & 1448 \\
\hline Skor Tertinggi & 63 & 58 \\
\hline Skor Terendah & 21 & 29 \\
\hline Rata-rata & 46,6 & 43,2 \\
\hline
\end{tabular}

Sedangkan Skor hasil pretest kemampuan hasil belajar siswa dapat dilihat pada Tabel 2.

Tabel 2. Perhitungan Skor Kemampuan Hasil Belajar Kognitif Berdasarkan Tes Awal (Pretest)

\begin{tabular}{ccc}
\hline \multicolumn{3}{c}{ Kelas } \\
\hline Perhitungan & $\begin{array}{c}\text { Eksperimen } \\
\text { (Model Think Pair } \\
\text { Share) }\end{array}$ & $\begin{array}{c}\text { Kontrol } \\
\text { (Model } \\
\text { Konvensional) }\end{array}$ \\
\hline Jumlah Skor & 1315 & 1380 \\
\hline Skor Tertinggi & 55 & 60 \\
\hline Skor Terendah & 30 & 25 \\
\hline Rata-rata & 42,4 & 40,5 \\
\hline
\end{tabular}


Berdasarkan hasil pretest atau pengukuran kemampuan awal siswa dari Tabel 1 rata-rata hasil prestasi siswa eksperimen untuk kemampuan berpikir kritis adalah 46,6 dan untuk kelas kontrol nilai rata-rata kemampuan berpikir kritis pada adalah 43,2. Sedangkan hasil pengukuran rata-rata prestasi hasil belajar kognitif kelas eksperimen pada Tabel 2 adalah 42,4 dan untuk kelas kontrol nilai rata- rata prestasi hasil belajar kognitif terlihat pada tabel 4.2 yakni 40,5. Sebelum melakukan uji-t harus periksa terlebih dahulu uji normalitas dan uji homogenitas varian. Uji normalitas data skor pretest hasil belajar siswa dilakukan menggunakan uji sampel KolmogorovSmirnov. Berikut hasil rekapitulasi perhitungan hasil belajar siswa pada pada kelas eksperimen dan kontrol.

a. Uji Normalitas dan Homogenitas Nilai pretest

Uji normalitas nilai pre-test pada model pembelajaran Think Pair Share dan konvensional dapat dilihat dibawah ini. Uji normalitas data skor pre-test kemampuan siswa menggunakan uji sampel Kolmogorov-Smirnov dengan sig >0,05. Rekapitulasi kemampuan awal pada kelas eksperimen dan kelas kontrol tersaji pada Tabel 3 dan Tabel 4.

Tabel 3. Uji Normalitas Skor Pretest Berpikir Kritis

\begin{tabular}{|c|c|c|c|}
\hline & & $\begin{array}{c}\text { Eksperimen } \\
\text { (Model } \\
\text { TPS) }\end{array}$ & $\begin{array}{c}\text { Kontrol } \\
\text { (Model } \\
\text { Konvensional) }\end{array}$ \\
\hline$\underline{N}$ & & $\underline{31}$ & $\underline{34}$ \\
\hline \multirow{2}{*}{$\underline{\text { Parameters }}^{\text {Nobmal }}$} & Mean & 46.65 & 43.29 \\
\hline & $\begin{array}{c}\text { Std } \\
\text { Deviation }\end{array}$ & $\underline{9.483}$ & $\underline{8.448}$ \\
\hline \multirow{3}{*}{$\begin{array}{c}\text { Most } \\
\text { Extreme } \\
\text { Differences }\end{array}$} & Absolute & .122 & .148 \\
\hline & Positive & .122 & .117 \\
\hline & Negative & -.118 & -.148 \\
\hline \multicolumn{2}{|c|}{ Kolmogorov Smirnov Z } & .680 & .862 \\
\hline \multicolumn{2}{|c|}{ Asymp. Sig. (2.tailed) } & .744 & .448 \\
\hline
\end{tabular}

Tabel 4. Uji Normalitas Skor Pretest Hasil Belajar Kognitif

\begin{tabular}{|c|c|c|c|}
\hline & & $\begin{array}{l}\text { Eksperimen } \\
\text { (Model } \\
\text { TPS) }\end{array}$ & $\begin{array}{c}\text { Kontrol } \\
\text { (Model } \\
\text { Konvensional) }\end{array}$ \\
\hline$\underline{N}$ & & 31 & 34 \\
\hline \multirow{2}{*}{${ }_{\text {Parameters }^{a b}}^{\text {Normal }}$} & Mean & 42.42 & $\underline{40.59}$ \\
\hline & $\frac{\text { Std }}{\text { Deviation }}$ & 7.624 & $\underline{10.714}$ \\
\hline \multirow{3}{*}{$\begin{array}{c}\frac{\text { Most }}{\text { Extreme }} \\
\text { Differences }\end{array}$} & Absolute & .141 & .130 \\
\hline & Positive & .141 & .111 \\
\hline & Negative & -.116 & -.760 \\
\hline \multicolumn{2}{|c|}{ Kolmogorov Smirnov Z } & .783 & .760 \\
\hline \multicolumn{2}{|c|}{ Asymp. Sig. (2.tailed) } & .572 & .610 \\
\hline
\end{tabular}

Berdasarkan Tabel 3 menunjukkan bahwa nilai pretest kemampuan berpikir kritis siswa kelas Think Pair Share (TPS) nilai signifikan $0,744>0,05$ dan kelas konvensional nilai signifikan 0,448 >0,05. Sedangkan pada Tabel 4 nilai pretest hasil belajar kognitif siswa kelas Think Pair Share (TPS) nilai signifikan 0,572 >0,05 dan kelas konvensional nilai signifikan $0,610>0,05$. Maka nilai pretest kemampuan berpikir kritis dan hasil belajar kognitif siswa kelas Think Pair Share (TPS) dan kelas konvensional pada sub pokok pencemaran lingkungan berdistribusi normal. Setelah diketahui normalitas data pretest dilanjutkan dengan uji homogenitas varian, dengan menggunakan uji Lavene's. Data uji homogenitas keterampilan berpikir kritis dan hasil belajar siswa dapat dilihat pada Tabel 5 dan Tabel 6.

Tabel 5. Uji Homogenitas Nilai Pretest Berpikir Kritis

\begin{tabular}{cccc}
\hline Levene Statistic & $\mathrm{df} 1$ & $\mathrm{df} 2$ & $\mathrm{Sig}$ \\
\hline 1.466 & 5 & 24 & .238 \\
\hline
\end{tabular}

Tabel 6. Uji Homogenitas Nilai Pretest Hasil Belajar Kognitif

\begin{tabular}{llll}
\hline Levene Statistic & $\mathrm{df1}$ & $\mathrm{df2}$ & $\mathrm{Sig}$ \\
\hline .562 & 7 & 23 & .779 \\
\hline
\end{tabular}

Pada Tabel 5 uji homogenitas nilai pretest berpikir kritis yang menggunakan model pembelajaran Think Pair Share (TPS) dan model pembelajaran konvensional nilai signifikan $0,238>0,05$. 
Dan pada tabel 6 uji homogenitas nilai pretest hasil belajar kognitif siswa nilai signifikan 0,779>0,05. Sehingga kita ketahui bahwa data pretest kemampuan awal siswa kelas Think Pair Share (TPS) dan kelas konvensional yang mempunyai varians yang homogen.

b. Uji Hipotesis Nilai Pretest Berpikir kritis dan Hasil Belajar Kognitif

Uji hipotesis pretest berpikir kritis dan hasil belajar kognitif dapat dilihat pada Tabel 7 dan Tabel 8.

Tabel 7. Menghitung Nilai Uji Hipotesis Pretest Berpikir Kritis

\begin{tabular}{|c|c|c|c|}
\hline & & Nilai Pretest & \\
\hline \multirow{3}{*}{$\begin{array}{l}\text { Levene's Test for Equality } \\
\text { of Variances }\end{array}$} & & Equal variances assumed & $\begin{array}{c}\text { Equal variances not } \\
\text { assumed }\end{array}$ \\
\hline & $F$ & 0.231 & \\
\hline & Sig & 0,632 & \\
\hline \multirow{7}{*}{$\begin{array}{l}t \text { - test for } \\
\text { Equality of } \\
\text { Means }\end{array}$} & $T$ & 1,507 & 1,499 \\
\hline & $D f$ & 63 & 60,385 \\
\hline & Sig. (2-tailed) & 0,137 & 0,139 \\
\hline & Mean Difference & 3,351 & 3,351 \\
\hline & Std. Error Difference & 2,224 & 2,236 \\
\hline & $95 \% \quad$ Lower & $-1,093$ & $-1,121$ \\
\hline & $\begin{array}{l}\text { Confidence Upper } \\
\text { Interval of the Difference }\end{array}$ & 7,795 & 7,823 \\
\hline
\end{tabular}

Berdasarkan Tabel 7 diketahui bahwa hasil uji-t pretest berpikir kritis siswa diperoleh nilai sig ( 2 tailed) atau $p$ value statistik sebesar $0,137>0,05$ dan diperoleh Thitung 1,507 sedangkan Ttabel 1,998, maka 1,507 < 1,998 (Ho diterima dan $\mathrm{Ha}$ ditolak). Hal ini berarti tidak ada perbedaan kemampuan awal berpikir kritis siswa untuk kedua kelas artinya kemampuan awal siswa pada kedua kelas itu sama. Maka dilanjutkan dengan uji posttest berpikir kritis siswa

Tabel 8. Menghitung Nilai Uji Hipotesis Pretest Hasil Belajar Kognitif

\begin{tabular}{|c|c|c|c|}
\hline & & Nilai Pretest & \\
\hline \multirow{3}{*}{$\begin{array}{l}\text { Levene's Test for } \\
\text { Equality of Variances }\end{array}$} & & Equal variances assumed & $\begin{array}{c}\text { Equal variances not } \\
\text { assumed }\end{array}$ \\
\hline & $F$ & 3.941 & \\
\hline & Sig & 0,051 & \\
\hline \multirow{7}{*}{$\begin{array}{l}t \text { - test for } \\
\text { Equality of } \\
\text { Means }\end{array}$} & $T$ & 0,787 & 0,799 \\
\hline & $d f$ & 63 & 59,607 \\
\hline & Sig. (2-tailed) & 0,434 & 0,427 \\
\hline & Mean Difference & 1,831 & 1,831 \\
\hline & Std. Error Difference & 2,327 & 2,292 \\
\hline & $95 \% \quad$ Lower & $-2,819$ & $-2,753$ \\
\hline & $\begin{array}{l}\text { Confidence Upper } \\
\text { Interval of the Difference }\end{array}$ & 6,481 & 6,415 \\
\hline
\end{tabular}

Berdasarkan tabel 8 diatas dapat dilihat dari hasil uji-t pretest hasil belajar kognitif siswa diperoleh nilai sig (2 tailed) atau $p$-value statistik sebesar
0,434 >0,05 dan diperoleh Thitung 0,787 sedangkan Ttabel 1,998, maka $0,787<1,998$ (Ho diterima dan $\mathrm{Ha}$ 
ditolak). Hal ini berarti tidak ada perbedaan kemampuan awal hasil belajar kognitif siswa untuk kedua kelas artinya kemampuan awal siswa pada kedua kelas tersebut sama. Maka dilanjutkan dengan uji posttest hasil belajar kognitif siswa

\section{Posttest Hasil Belajar}

Data mengenai nilai posttest kemampuan berpikir kritis peserta didik dapat dilihat pada Tabel 9.

Tabel 9. Perhitungan Skor Kemampuan Berpikir Kritis Berdasarkan Tes Akhir (Posttest)

\begin{tabular}{ccc}
\hline & \multicolumn{2}{c}{ Kelas } \\
\hline Perhitungan & $\begin{array}{c}\text { Eksperimen } \\
\text { (Model Think Pair } \\
\text { Share) }\end{array}$ & $\begin{array}{c}\text { Kontrol } \\
\text { (Model Konvensional) }\end{array}$ \\
\hline Jumlah Skor & 2539 & 1899 \\
\hline Skor Tertinggi & 96 & 79 \\
\hline Skor Terendah & 54 & 38 \\
\hline Rata-rata & 81,9 & 55,8
\end{tabular}

Data mengenai nilai posttest hasil belajar peserta didik dapat dilihat pada Tabel 10.

Tabel 10. Perhitungan Skor Kemampuan Hasil Belajar Kognitif Berdasarkan Tes Akhir (Posttest)

\begin{tabular}{ccc}
\hline & \multicolumn{2}{c}{ Kelas } \\
\hline Perhitungan & $\begin{array}{c}\text { Eksperimen } \\
\text { (Model Think Pair } \\
\text { Share) }\end{array}$ & $\begin{array}{c}\text { Kontrol } \\
\text { (Model } \\
\text { Konvensional) }\end{array}$ \\
\hline Jumlah Skor & 2665 & 2725 \\
\hline Skor Tertinggi & 100 & 100 \\
\hline Skor Terendah & 70 & 60 \\
\hline Rata-rata & 85,9 & 80,1
\end{tabular}

Sebelum melakukan uji-t harus periksa terlebih dahulu uji normalitas dan uji homogenitas varian. Uji normalitas data skor post-test hasil belajar siswa menggunakan uji sampel KolmogorovSmirnov. Berikut hasil rekapitulasi perhitungan hasil belajar siswa pada sub pokok pencemaran lingkungan pada kelas eksperimen dan kontrol.

a. Uji Normalitas dan Homogenitas Nilai Post-test

Uji normalitas nilai Post-test pada model pembelajaran Think Pair Share dan konvensional dilakukan menggunakan uji sampel Kolmogorov-Smirnov dengan sig $>0,05$. Data uji normalitas skor posttest berpikir kritis dapat dilihat pada Tabel 11.

Tabel 11. Uji Normalitas Skor Post-test Berpikir Kritis

\begin{tabular}{|c|c|c|c|}
\hline & & $\begin{array}{l}\text { Eksperimen } \\
\text { (Model TPS) }\end{array}$ & $\begin{array}{l}\text { Kontrol (Model } \\
\text { Konvensional) }\end{array}$ \\
\hline$\underline{N}$ & & 31 & 34 \\
\hline \multirow{2}{*}{${ }_{\text {Parameters }^{a b}}^{\text {Normal }}$} & Mean & 83.13 & 55,85 \\
\hline & $\begin{array}{c}\frac{\text { Std }}{\text { Deviation }} \\
\underline{\underline{n}}\end{array}$ & $\underline{8.865}$ & 10.302 \\
\hline Most Extreme & Absolute & .128 & .160 \\
\hline \multirow[t]{2}{*}{ Differences } & Positive & .099 & .160 \\
\hline & Negative & -.128 & -.096 \\
\hline \multicolumn{2}{|c|}{ Kolmogorov Smirnov Z } & .713 & .931 \\
\hline \multicolumn{2}{|c|}{ Asymp. Sig. (2.tailed) } & .690 & .352 \\
\hline
\end{tabular}

Data mengenai uji normalitas posttest hasil belajar peserta didik dapat dilihat pada Tabel 12.

Tabel 12. Uji Normalitas Skor Posttest Hasil Belajar Kognitif

\begin{tabular}{|c|c|c|c|}
\hline & & $\begin{array}{l}\text { Eksperimen } \\
\text { (Model TPS) }\end{array}$ & $\begin{array}{l}\text { Kontrol (Model } \\
\text { Konvensional) }\end{array}$ \\
\hline$\underline{N}$ & & 31 & 34 \\
\hline \multirow{2}{*}{${ }_{\text {Parameters }}^{\text {Normal }^{a b}}$} & Mean & 85.97 & 80.15 \\
\hline & $\begin{array}{c}\frac{\text { Std }}{\text { Deviation }} \\
\end{array}$ & 10.834 & 10.835 \\
\hline \multirow{3}{*}{$\frac{\text { Most Extreme }}{\text { Differences }}$} & Absolute & .153 & .143 \\
\hline & Positive & .135 & .124 \\
\hline & Negative & -.153 & -.143 \\
\hline \multicolumn{2}{|c|}{ Kolmogorov Smirnov Z } & .850 & .837 \\
\hline \multicolumn{2}{|c|}{ Asymp. Sig. (2.tailed) } & .466 & .486 \\
\hline
\end{tabular}

Berdasarkan Tabel 11 menunjukkan bahwa nilai posttest kemampuan berpikir kritis siswa kelas Think Pair Share (TPS) nilai signifikan $0,690>0,05$ dan kelas konvensional nilai signifikan 0,352>0,05. Sedangkan pada Tabel 12 nilai posttest hasil belajar kognitif siswa kelas Think Pair Share (TPS) nilai signifikan 0,466 $>0,05$ dan 
kelas konvensional nilai signifikan 0,486 $>0,05$. Maka nilai posttest kemampuan berpikir kritis dan hasil belajar kognitif siswa kelas Think Pair Share (TPS) dan kelas konvensional berdistribusi normal. Setelah diketahui normalitas data posttest dilanjutkan dengan uji homogenitas varian, dengan menggunakan uji Lavene's. Untuk nilai uji homogenitas posstest berpikir kritis dapat dilihat pada Tabel 13.

Tabel 13. Uji Homogenitas Nilai Posttest Berpikir Kritis

\begin{tabular}{cccc}
\hline Levene Statistic & $\mathrm{df1}$ & $\mathrm{df2}$ & Sig \\
\hline 2.308 & 9 & 20 & .062 \\
\hline
\end{tabular}

Sedangkan data mengenai nilai homogenitas posstest hasil belajar peserta didik dapat dilihat pada Tabel 14.
Tabel 14. Uji Homogenitas Nilai Posttest Hasil Belajar Kognitif

\begin{tabular}{llll}
\hline Levene Statistic & $\mathrm{df1}$ & $\mathrm{df2}$ & $\mathrm{Sig}$ \\
\hline 2.472 & 6 & 22 & .056 \\
\hline
\end{tabular}

Pada Tabel 13 uji homogenitas nilai posttest berpikir kritis kelas eksperimen menggunakan model pembelajaran Think Pair Share (TPS) dan kelas kontrol menggunakan model pembelajaran konvensional nilai signifikan 0,062>0,05. Dan pada Tabel 14 uji homogenitas nilai posttest hasil belajar kognitif siswa nilai signifikan $0,056>0,05$. Sehingga kita ketahui bahwa data posttest kemampuan akhir siswa kelas Think Pair Share (TPS) kelas konvensional mempunyai varians yang homogen

b. Uji Hipotesis Nilai Posttest Berpikir kritis dan Hasil Belajar Kognitif

Data mengenai uji hipotesis nilai posttest berpikir kritis peserta didik dapat dilihat pada Tabel 15.

Tabel 15. Menghitung Nilai Uji Hipotesis Posttest Berpikir Kritis

\begin{tabular}{|c|c|c|c|}
\hline & & Nilai Pretest & \\
\hline \multirow{3}{*}{$\begin{array}{l}\text { Levene's Test for Equality } \\
\text { of Variances }\end{array}$} & & Equal variances assumed & $\begin{array}{c}\text { Equal variances not } \\
\text { assumed }\end{array}$ \\
\hline & $F$ & 0.344 & \\
\hline & Sig & 0,560 & \\
\hline \multirow{7}{*}{$\begin{array}{l}\text { - test for } \\
\text { Equality of } \\
\text { Means }\end{array}$} & $t$ & 10,262 & 10,270 \\
\hline & $d f$ & 63 & 62.625 \\
\hline & Sig. (2-tailed) & 0,000 & 0,000 \\
\hline & Mean Difference & 26,050 & 26,050 \\
\hline & Std. Error Difference & 2,539 & 2,547 \\
\hline & $95 \% \quad$ Lower & 20,977 & 20,981 \\
\hline & $\begin{array}{l}\text { Confidence Upper } \\
\text { Interval of the Difference }\end{array}$ & 31,123 & 31,120 \\
\hline
\end{tabular}

Berdasarkan Tabel 15 di atas dapat dilihat dari hasil uji-t berpikir kritis siswa diperoleh nilai sig ( 2 tailed) atau $p$ value statistik sebesar $0,000<0,05$ dan diperoleh Thitung 10,262 sedangkan Ttabel 1,998, maka 10,262>1,998 (Ho ditolak dan Ha diterima). Hal ini berarti terdapat perbedaan berpikir kritis siswa dengan model pembelajaran Think Pair Share (TPS) di MAN 2 Kota Bengkulu. Data mengenai uji hipotesis nilai posttest hasil belajar peserta didik dapat dilihat pada Tabel 16. 
Tabel 16. Menghitung Nilai Uji Hipotesis Posttest Hasil Belajar Kognitif

\begin{tabular}{|c|c|c|c|}
\hline & \multicolumn{3}{|c|}{ Nilai Pretest } \\
\hline \multirow{3}{*}{$\begin{array}{l}\text { Levene's Test for } \\
\text { Equality of Variances }\end{array}$} & & Equal variances assumed & $\begin{array}{c}\text { Equal variances not } \\
\text { assumed }\end{array}$ \\
\hline & $F$ & 0,007 & \\
\hline & Sig & 0,931 & \\
\hline \multirow{7}{*}{$\begin{array}{l}t \text { - test for } \\
\text { Equality of } \\
\text { Means }\end{array}$} & $t$ & 2,163 & 2,163 \\
\hline & $d f$ & 63 & 62,451 \\
\hline & Sig. (2-tailed) & 0,034 & 0,034 \\
\hline & Mean Difference & 5,821 & 5,821 \\
\hline & Std. Error Difference & 2,691 & 2,691 \\
\hline & 95\% $\quad$ Lower & 0,444 & 0,442 \\
\hline & $\begin{array}{l}\text { Confidence Upper } \\
\text { Interval of the Difference }\end{array}$ & 11,197 & 11,198 \\
\hline
\end{tabular}

Berdasarkan Tabel 16 diatas dapat dilihat dari hasil uji-t hasil belajar kognitif siswa diperoleh nilai sig (2 tailed) atau $p$-value statistik sebesar 0,034<0,05 dan diperoleh Thitung 2,163 sedangkan Ttabel 1,998, maka 2,163>1,998 (Ho ditolak dan Ha diterima). Hal ini berarti perbedaan hasil belajar kognitif siswa dengan model pembelajaran Think Pair Share (TPS) di MAN 2 Kota Bengkulu.

Pada proses pembelajaran guru membagikan Lembar Kerja Siswa (LKS) kepada seluruh siswa secara individu. Selanjutnya siswa dikelompokkan dengan pasangannya dengan melakukan praktikum dan berdiskusi mengenai permasalahan pada pokok bahasan pencemaran lingkungan. Setelah mereka berdiskusi dengan pasangannya guru memanggil satu pasang siswa secara acak untuk berbagi pendapat mengenai masalah yang telah mereka diskusikan kepada seluruh siswa di kelas.

Guru mengoptimalkan indikator kemampuan berpikir kritis siswa dengan memberikan soal untuk mengatasi permasalahan yang diberikan tentang pencemaran lingkungan. Indikator kemampuan berpikir kritis yang dikembangkan siswa berupa merumuskan masalah dalam pertanyaan, memberikan argumen sesuai dengan kebutuhan, mendeduksi secara logis, menganalisis data serta menarik kesimpulan, mengevaluasi berdasarkan fakata, dan memberikan jalan keluar yang akan dilaksanakan.

Berpikir kritis merupakan suatu pola berpikir yang berguna untuk merumuskan jawaban atau mencari solusi dalam memecahkan suatu masalah. Berpikir kritis sangat penting diajarkan dan dikembangkan oleh setiap guru kepada siswanya agar mereka dapat memikirkan strategi-strategi yang dapat memecahkan dan mencari solusi dari permasalahan. Hal ini didukung oleh pendapat Mamu (2014) menyatakan bahwa keterampilan berpikir kritis merupakan aspek yang penting dan sangat dibutuhkan oleh setiap individu dalam mengatasi berbagai permasalahan kompleks dalam kehidupan. Keterampilan berpikir kritis perlu dioptimalkan melalui proses pembelajaran di sekolah.

Model pembelajaran kooperatif yaitu suatu model pembelajaran dimana setiap siswa belajar dalam kelompok kecil yang memiliki tingkat kemampuan yang berbeda pada setiap siswa dalam menyelesaikan tugas kelompok, sertai anggota saling kerja sama dan membantu untuk memahami suatu bahan pembelajaran. Hal ini sejalan 
dengan pendapat AL-Tabany (2014) menyatakan bahwa pembelajaran kooperatif muncul dari konsep bahwa siswa akan lebih mudah menemukan dan memahami konsep yang sulit jika mereka saling berdiskusi dengan temannya. Siswa secara rutin bekerja dalam kelompok untuk saling membantu memecahkan masalah.

Model pembelajaran Think Pair Share (TPS) merupakan bagian dari model pembelajaran kooperatif, dimana model TPS dirancang untuk mempengaruhi pola interaksi siswa, sangat efektif untuk membuat variasi suasana pola diskusi kelas. Model pembelajaran Think Pair Share (TPS) memberikan kesempatan yang banyak kepada siswa untuk berfikir, menjawab, dan saling membantu satu sama lain. Hal ini juga sejalan dengan pendapat Arends (2008) bahwa model pembelajaran TPS dapat mengaktifkan seluruh siswa selama proses pembelajaran dan memberi kesempatan untuk bekerja sama antar siswa.

Pada model pembelajaran Think Pair Share (TPS) siswa lebih banyak kesempatan untuk berkontribusi dengan masing-masing anggota kelompok untuk menyampaikan idenya sebelum di diskusikan di depan kelas. Adanya kemudahan interaksi sesama siswa menjadikan siswa lebih memiliki rasa percaya diri dan tanggung jawab untuk menyelesaikan permasalahan yang diberikan oleh guru. Hasil temuan ini sesuai diungkapkan Boleng (2014) dan Surayya, dkk (2014) bahwa model pembelajaran secara signifikan berpengaruh terhadap sikap sosial, meningkatkan keterampilan berpikir kritis, dan hasil belajar kognitif.

Dari hasil penelitian didapatkan bahwa terdapat pengaruh yang sangat signifikan antara kedua kelas pembelajaran terhadap kemampuan berpikir kritis siswa yang diajarkan dengan model pembelajaran Think Pair Share (TPS) dan konvensional. Dimana kelas eksperimen pada kelas X MIA 1 lebih besar rata-ratanya dibandingkan kelas kontrol pada kelas X MIA 3 . Perbedaan ini terjadi karena adanya perlakuan pada kedua kelas yaitu kelas $X$ MIA 1 menggunakan model pembelajaran Think Pair Share dan kelas $X$ MIA 3 yang menggunakan model pembelajaran konvensional. Hasil temuan selanjutnya juga diungkapkan oleh Mentari (2015) menyatakan bahwa kemampuan berpikir kritis kelas eksperimen lebih tinggi dibandingkan kelas kontrol.

Pada proses pembelajaran, guru sangat mendukung perkembangan hasil belajar peserta didik. Menurut Irwandi (2010) hasil belajar ialah perubahan perilaku akibat proses belajar. Melalui kegiatan belajar, seseorang memiliki kemampuan, pengetahuan, dan keterampilan tertentu sesuai dengan pengetahuan yang di dalamnya. Hasil belajar meliputi tiga ranah (domain) yaitu kognitif, afektif, dan psikomotor. Domain kognitif ialah berupa kemampuan intelektual yang terdiri atas enam bagian yaitu pengetahuan, pemahaman, penerapan, analisis, sintesis, dan evaluasi. Ada enam (6) kategori hasil belajar kognitif berdasarkan domain kognitif Taxonomy Bloom revisi Anderson \& Krathwohl (2001) yaitu: (1) mengingat, (2) memahami, (3) menerapkan, (4) menganalisis, (5) evaluasi, dan (6) mencipta.

Model Think Pair Share (TPS) memberi kesempatan yang lebih banyak kepada siswa untuk menunjukkan partisipasi mereka kepada orang lain. Pemecahan masalah dapat dilakukan secara langsung dan siswa dapat memahami suatu materi secara berkelompok dan saling membantu satu sama lain. Siswa akan terlatih untuk 
membuat konsep pemecahan masalah, sehingga keaktifan siswa meningkat karena masing-masing siswa dapat dengan leluasa mengeluarkan pendapat mereka. Siswa memperoleh kesempatan untuk mempresentasikan hasil diskusinya kepada seluruh siswa sehingga ide yang mereka dapatkan menyebar pada setiap anak.

Model pembelajaran Think Pair Share (TPS) dirancang untuk mempengaruhi pola interaksi siswa, sangat efektif untuk membuat variasi suasana pola diskusi kelas. Memberikan kesempatan yang banyak kepada siswa untuk berpikir, menjawab, dan saling membantu satu sama lain. Hasil temuan ini sejalan dengan pendapat Dewi (2015) menyatakan bahwa model pembelajaran Think Pair Share (TPS) merangsang siswa untuk berpikir, permasalahan berupa kontekstual, serta berpasangan untuk bekerja sama dalam menyelesaikan permasalahan.

Peningkatan hasil belajar pada kedua kelas berbeda secara signifikan. Hasil belajar lebih mendalam karena model pembelajaran TPS siswa dituntut untuk dapat belajar berempati, menerima pendapat orang lain, atau mengaku secara sportif jika pendapatnya tidak diterima. Sehingga model Think Pair Share (TPS) lebih efektif dari pada model konvensional. Hasil temuan ini sesuai diungkapkan oleh Boleng (2014) menyatakan bahwa model pembelajaran berpengaruh terhadap hasil belajar kognitif siswa. Penerapan model pembelajaran kooperatif mampu meningkatkan hasil belajar kognitif siswa biologi.

Dari hasil penelitian didapatkan bahwa terdapat pengaruh yang sangat signifikan anatar kedua kelas pembelajaran terhadap hasil belajar kognitif siswa yang diajarkan dengan model pembelajaran Think Pair Share dan konvensional. Dimana kelas eksperimen pada kelas X MIA 1 lebih besar rata-ratanya dibandingkan kelas kontrol pada kelas X MIA 3 . Perbedaan ini terjadi karena adanya perlakuan pada kedua kelas yaitu kelas $X$ MIA 1 menggunakan model pembelajaran Think Pair Share dan kelas $X$ MIA 3 menggunakan model pembelajaran konvensional. Hal ini sejalan dengan pendapat Surayya, dkk (2014) menyatakan bahwa terdapat perbedaan hasil belajar antara siswa yang mengikuti model pembelajaran TPS dengan siswa yang mengikuti model pembelajaran konvensional

\section{PENUTUP \\ Simpulan}

Berdasarkan hasil penelitian tentang kemapuan berpikir kritis dan hasil belajar kognitif siswa menggunakan model pembelajaraan kooperatif type Think Pair Share (TPS) yang menggunakan model pembelajaran konvensional di MAN2 Kota Bengkulu dapat disimpulkan bhawa: Terdapat pengaruh model pembelajaraan kooperatif type Think Pair Share (TPS) terhadap kemampuan berpikir kritis dan hasil belajar kognitif siswa di MAN 2 Kota Bengkulu. Pembelajaran dengan model Think Pair Share (TPS) dapat meningkatkan berpikir kritis dan hasil belajar kognitif siswa sebesar 88,9 dan 85,9 .

\section{Saran}

Hasil penelitian ini dapat digunakan sebagai acuan untuk penelitian selanjutnyayang menggunakan model pembelajaran Think Pair Share (TPS) dan model pembelajaran lainnya, terutama untuk meningkatkan hasil belajar berpikir kritis dan hasil belajar kognitif siswa yang didukung oleh pihak sekolah dengan menyediakan fasilitas maupun sarana 
dan prasarana yang mendukung dalam kegiatan pembelajaran untuk meningkatkan proses belajar siswa disekolah.

\section{DAFTAR PUSTAKA}

Al-Tabany, T.I.B. 2014. Mendesain Model Pembelajaran Inovatif, Progresif, dan Kontekstual. Prenadamedia Group. Jakarta.

Arends, Richard. (2008). Learning to Teach. Pustaka Pelaja. Jogjakarta

Boleng, D.T. 2014. Pengaruh Model Pembelajaran Cooperative Script dan Think-Pair-Share terhadap Keterampilan Berpikir Kritis, Sikap Sosial, dan Hasil Belajar Kognitif Biologi Siswa SMA Multietnis. Pendidikan Sains 2(2):76-84.

Dewi, A. 2015. Penerapan Model Pembelajaran Think Pair Share (TPS) Dipadukan Dengan Problem Based Learning (PBL) Dalam Meningkatkan Kemampuan Berpikir Kritis Siswa. Skripsi Program Study Pendidikan Fisika FKIP UNS. Semarang.

Dimyati dan Mudjiono. 2013. Belajar dan Pembelajaran. Rineka Cipta. Jakarta.

Ennis, R. H. dkk (2005). Critical Thinking Test. USA: Bright Minds.

Feldman, A.D. 2010. Berpikir Kritis. Indeks. Jakarta.

Fisher, A. 2008. Berpikir Kritis. Erlangga. Jakarta.

Hamzah dan Uno. 2008. Perencanaan Pembelajaran. PT. Bumi Aksara. Jakarta.

Irwandi. 2010. Strategi Pembelajaran Biologi Berbasis Kontekstual. UMB Press.Bengkulu.

Krathwohl, D., R. 2002. A Revision of Bloom,s Taxonomy An Overview. Theory Into Practice, 41 (4), hal. 212-218.
Kurniasih, I dan Sani, B. 2015. Ragam Pengembangan Model

Pembelajaran. Kata Pena. Jakarta.

Kuswana, W.S. 2011. Taksonomi Berpikir. PT. Remaja Rosdakarya. Bandung.

Mamu, H.D. 2014. Pengaruh Strategi Pembelajaran, Kemampuan Akademik dan Interaksinya terhadap Keterampilan Berpikir Kritis dan Hasil Belajar Kognitif IPA Biologi. Pendidikan Sains 2(1): 1-11.

Mentari, W. 2015. Pengaruh Model Discovery Learning Terhadap Kemampuan Berpikir Kritis Dan Hasil Belajar Siswa. Artikel Universitas Lampung. Lampung.

Ruswandi. 2013. Psikologi Pembelajaran. Cipta Pesona Sejahtera. Bandung. Slameto. 2010. Belajar dan FaktorFaktor Yang mempengaruhinya. Rineka Cipta. Jakarta.

Surayya, L., Subagia, I.W., dan Tika, I.N. 2014. Pengaruh Model Pembelajaran Think Pair Share Terhadap Hasil Belajar Ipa Ditinjau Dari Keterampilan Berpikir Kritis Siswa. e-Journal Program Pascasarjana Universitas Pendidikan Ganesha Program Studi IPA (4): 111.

Tirtarahardja, Umar dan Sulo, S.,L.,L. 2010. Pengantar Pendidikan, Rineka Cipta. Jakarta 